\title{
Ethnic fertility behavior and internal migration in Nigeria: revisiting the migrant fertility hypotheses
}

\author{
Clifford O. Odimegwu ${ }^{1}$ and Yemi Adewoyin ${ }^{1,2^{*}}$ (D)
}

\author{
* Correspondence: yemiadewoyin@ \\ yahoo.com \\ ${ }^{1}$ Demography and Population \\ Studies Programme, Schools of \\ Public Health and Social Sciences, \\ University of the Witwatersrand, \\ Johannesburg, South Africa \\ ${ }^{2}$ Department of Geography, Faculty \\ of the Social Sciences, University of \\ Nigeria, Nsukka, Nigeria
}

\begin{abstract}
Fertility patterns in Nigeria are high and widely skewed away from the targets of the country's population policy. As population growth is fueled by natural increase and migration, and with spatial disparities in fertility preferences among the different ethnic groups in Nigeria, this study investigates the fertility behavior of ethnic migrants in their destinations, the place-effects on such behavior, and the convergence or otherwise of the behavior with fertility behaviors in the migrants' places of origin and destination. Explanations for the behavioral pattern are provided in the hypotheses of migrant fertility and in the sociodemographic confounders of the behavior. Study data was extracted for the three major ethnic groups in Nigeria from the Nigerian Demographic and Health Survey. Median numbers of children ever born (CEB) were 7, 6, and 4 for the HausaFulani, Igbo, and Yoruba ethnic groups respectively. Relative to the destination fertility patterns, Hausa-Fulani and Yoruba migrants had lower CEB in Igboland while Igbo and Yoruba migrants recorded lower CEB in the North-West home of the Hausa-Fulani ethnic group. Whereas the Igbo migrants maintained an equal CEB with their Yoruba hosts, the Hausa-Fulani group replicated their home fertility behavior in Yorubaland. Overall, the adaptation, socialization, and selectivity hypotheses were found valid for some of the disparities in migrant fertility behavior and the influence of the sociodemographic predictors of fertility behavior varied among the different ethnic groups.

Keywords: Fertility behavior, Internal migration, Ethnicity, Adaptation hypothesis, Socialization hypothesis, Selectivity hypothesis, Hausa-Fulani, Igbo, Yoruba, Nigeria
\end{abstract}

\section{Introduction}

Nigeria is characterized by marked and well-documented disparity in levels of development and access to livelihood opportunities, social services, and basic infrastructures among its regions and political subdivisions, and between its urban and rural areas. Internal migration among the population has become a major strategy employed for addressing these deficiencies and for enhancing access to the livelihood opportunities. How well internal migration has worked as a livelihood diversification strategy, its nature and dynamics, and its consequences for social and economic development at individual, households, community, national, and regional levels have been the crux of several studies in Nigeria; Adepoju (1978 and 1982), Gugler (1991), Mberu (2005), Aworemi and Abdul-Azeez (2011), Oyeniyi

(c) The Author(s). 2020 Open Access This article is licensed under a Creative Commons Attribution 4.0 International License, which permits use, sharing, adaptation, distribution and reproduction in any medium or format, as long as you give appropriate credit to the original author(s) and the source, provide a link to the Creative Commons licence, and indicate if changes were made. The images or other third party material in this article are included in the article's Creative Commons licence, unless indicated otherwise in a credit line to the material. If material is not included in the article's Creative Commons licence and your intended use is not permitted by statutory regulation or exceeds the permitted use, you will need to obtain permission directly from the copyright holder. To view a copy of this licence, visit http://creativecommons.org/licenses/by/4.0/. 
(2013), Ajaero and Madu (2014), Abizu (2018), and Farrell (2018) for instance. The copious magnitude of these studies notwithstanding, studies linking internal migration with sexual behavior, reproductive health, and contraceptive use in Nigeria are very few (Smith, 2004; Mberu and White, 2011; Akinyemi et al., 2017). Much fewer and virtually non-existent are those on the association between internal migration and fertility behavior. While the two available studies, Makinwa-Adebusoye (1985) and Omoyeni (2013), investigated fertility differentials among migrants and non-migrants, nothing is known about the fertility behavior of migrants in their destination locations, the place-effects on such behavior, and the convergence or otherwise of the behavior with behaviors in the migrants' places of origin and destination.

An understanding of the interrelatedness of internal migration and fertility behavior in Nigeria is important for several reasons. Chief among them being its implications for population growth and control, and for addressing regional inequality in social and economic development. Both are, however, not mutually exclusive. Nigeria has 37 States (including a Federal Capital Territory), nearly 800 local government areas (LGAs), each housing a settlement or an assemblage of settlements, and over 380 ethnic groups (National Population Commission (NPC) [Nigeria] and ICF, 2014). As such, internal migration in Nigeria takes the forms of rural-urban, rural-rural, urban-urban, and urban-rural migration (Oyeniyi, 2013) across the various settlements, LGAs, and States. According to the 2010 national internal migration survey in Nigeria, the proportion of migrant households ranged from $10.5 \%$ in Bauchi and Gombe States to $44.4 \%$ in Abia State with a national average of 23\% (National Population Commission [NPC], 2010). This suggests that the push and pull factors driving the movements vary among places and present an opportunity for understanding and addressing development inequality in space. Achieving this rests on a knowledge of population distribution in places, its associated demographic dynamics, as well as its rate and pattern of change consequent on natural increase and immigration. Thus, not only do migrants fuel population growth in their destinations, they also contribute to the natural increase in those destinations through their fertility behavior.

Fertility behavior has been found to have a spatial dimension and varies among places and between urban and rural areas across the world (Kulu and Boyle, 2009; Kulu, 2013; Fiori et al., 2014; Odimegwu and Adedini, 2017; Jung et al., 2019). The situation is not different in Nigeria where it has further been shown to vary among different ethnic groups (Odimegwu, 1999; Ushie et al., 2011; Mberu and Reed, 2014; Odimegwu et al., 2014; Alaba et al., 2017; Adebowale, 2019). For instance, when expressed in terms of total fertility rates (TFR), the fertility pattern in rural Nigeria is 5.9 births while it is 4.5 in the urban centers (National Population Commission (NPC) [Nigeria] and ICF, 2019). In their 2013 Demographic and Health Survey report, NPC and ICF (2014) put the rates at 6.2 and 4.7 for rural and urban areas respectively. In the regions, the average TFR was 4.3 in the South-South, 4.6 in the South-West, 4.7 in the South-East, 5.3 in North-Central, 6.3 in the North-East, and 6.7 in North-West Nigeria. Beneath the regional average however, the TFR in the States ranged from 3.8 in Rivers; 4.1 in Lagos; 4.2 in Abia, Anambra, and Kogi States to 7.6 in Jigawa; 8.1 in Bauchi; and 8.4 in Zamfara States. With an estimated population of 200 million, projected to double by the year 2050 (United Nations, 2019), and a national policy that targeted a reduction in the country's population growth rate to $2 \%$ by the year 2000, and a further decline by 2015 (NPC Nigeria, 1988, 2004), understanding the pattern matters for population control. 
Given this background, do migrants, then, relocate with the fertility behavior associated with their places of origin and exhibit same in their destinations? Or do they adapt to the fertility behavior of their destinations? Evidence suggests that at international level, both positions hold true among immigrants (Kulu, 2005; Milewski, 2010; Eryurt and Koc, 2012; Liang et al., 2014; Krapf and Wolf, 2015; Rojas et al., 2018; Kulu et al., 2019; Saikia et al., 2019). In certain instances, even the fertility rates among migrants were found to be lower than what obtained in both their places of origin and destinations (Hervitz, 1985; GonzálezFerrer et al., 2017). In the studies, some confounding factors that influenced the outcomes included transition to second and third births, length of stay, socioeconomic characteristics of the migrants and whether or not the migrants themselves were the original settlers, relocated with their parents as children, or were born in the destination locations. At a subnational level, and among Sub-Saharan African countries where rural-urban migration is rife, Banougnin et al. (2018) observed that rural migrants to Cotonou had initial higher fertility rates which gradually converged with the fertility pattern obtained in the capital city with the passage of time. Anglewicz et al. (2017) found similar evidence of higher fertility among migrants in Kinshasa. In contrast, Gyimah (2006) found out that, relative to non-migrants, fertility was lower among recent migrants but higher among migrants who had stayed longer at the destination. Omoyeni (2013) also reported lower fertility among migrants. Omondi and Ayiemba (2005) had attributed such pattern in Kenya to female migrants' relegation of their reproductive roles for self-actualization activities like career development.

Explanations to understanding the contrasting fertility behavior among migrants have been grounded in five competing, yet complimentary, hypotheses. These are the disruption, interrelation of events, selectivity, socialization, and adaptation hypotheses (Goldstein and Goldstein, 1983,1984; Hervitz, 1985; Lee and Pol, 1993; Kulu, 2005; Milewski, 2010; Krapf and Wolf, 2015; Gonzalez-Ferrer et al., 2017). While the disruption hypothesis posits that fertility of migrants is negatively affected by the stress associated with the migration itself, such as preparation for relocation, the actual relocation, or separation from spouse, the interrelation of events suggests that migrants record high fertility owing to a reunification with family, marriage, and union formation after the migration. In both instances, the reduction or increase in the migrant's fertility is temporary. Essentially, both hypotheses are opposite sides of the same coin and are dependent on the time factor. The selectivity hypothesis on the other hand argues that migrants have distinguishing characteristics that set them apart from both the population at origin and destination, even though those characteristics may be quite similar to those of the population at destination. As such, they exhibit a fertility behavior that differs from those at origin and destination. Hervitz (1985) and Gonzalez-Ferrer et al (2017) contended that these group of migrants are not a random sample but share selected attributes with respect to age, marital status, socioeconomic background, and social mobility aspirations that guide their basis for migration and choice of destination.

The central argument of the adaptation hypothesis is simply that the fertility behavior of migrants will converge on that of the destination population. The convergence, according to Hervitz (1985), is usually rapid. In other words, the hypothesis argues that the economic, social, and cultural environment at destination will force migrants to adapt their fertility behavior to what obtains at the destination (Gonzelez-Ferrer et al., 2017). Cost of living and child rearing, for instance, may condition such adaptation (Frank and Heuveline 2005), just as the social and cultural norms at the destination are expected to trigger a behavioral change among the migrants through a process of social 
interaction (Gyimah, 2006). The socialization hypothesis on the other hand is based on the assumption that, at their destinations, migrants will exhibit fertility behavior that reflects that of the population at their places of origin. The hypothesis argues that fertility behavior is a cultural norm that formed part of the childhood experiences of the migrants and left a lasting imprint in the minds of the migrants. Such internalized values are therefore exhibited in the migrants' fertility preferences at destinations (Goldstein and Goldstein, 1984; Milewski, 2007, 2010; Krapf and Wolf, 2015). Simply put, 'the fertility behavior of migrants reflects the fertility preferences prevalent in their childhood environment' (Hervitz, 1985, p. 293). Barber (2000), Nauck (2001), and Milewski (2011) have further shown that these values and fertility preferences are transmittable from one generation of migrants to the next generation through socialization.

As ethnicity offers a more discernable level of differentiating fertility behavior among the population in Nigeria, this study assesses the association between internal migration and fertility behavior at the level of ethnic groups in the country. It also investigates the influence of sociodemographic characteristics of the migrants on the behavior. With Nigeria's 37 States aggregated into six geopolitical regions of largely similar ethnic groups and identical cultural characteristics and social norms, internal migration in this study is conceptualized as migration across the geopolitical divides. Consequently, we proceed to investigate and compare the fertility behaviors of the ethnic groups and those of the migrant population from the ethnic groups at their various destinations. We further ask if the patterns imitate and confirm any of the adaptation, socialization, or selectivity hypotheses of migration and fertility. The choice of the three hypotheses, out of the relevant five, is predicated on the transient nature of both disruption and interrelated events which suggests that their applicability is most suited for recent migration events.

The study findings are expected to pioneer a discourse on the role of ethnic fertility and other cultural attributes on migration and development in Nigeria, influence national population and development policies, provide a national vista to international debates and add to the body of knowledge on migration and fertility behavior, and confirm the relevance of the migration and fertility hypotheses at subnational levels. The findings are equally expected to prepare the grounds for further studies on the political dimensions of ethnic fertility behavior in Nigeria. Specifically, Nigeria, being a multi-ethnic state, is faced with the problem of diversity of opinions on and compliance level with several public policies consequent on the interpretations given such policies by the various ethnic groups who live in constant mistrust and suspicion of one another. In the prevailing context, there are local tales of how the Hausa-Fulani and Igbo ethnic groups are seeking to outnumber the Yoruba population in the South-West with their fertility behavior, same way the Hausa-Fulani are said to be becoming more ubiquitous in Igbo land. Underlying these tales are the issues of political representation, allocation of public goods, and access to political power. These dimensions are very consequential in a country that is largely public sector driven and where the instruments for addressing regional development inequality lie with the political class.

\section{Methodology}

\section{Population and sampling}

The 2006 national population census put the population of Nigeria, the study area, at a little over 140 million. Current estimates suggest the country is inhabited by about 200 
million people. This population is spread across 36 States and a Federal Capital Territory. These administrative units are further subdivided into local government areas (LGAs), which are in turn divided into localities or settlements and further into wards or enumeration areas (EAs) for the purposes of political participation and population-related activities respectively. At the national level, the States are grouped into geopolitical regions to reflect cultural background, contiguity, and common values. These regions, however, do not have administrative structures but serve to preserve national policies on quota system and federal character in appointments, location, and allocation of public goods and services and related matters. While the North-West, South-East, and South-West regions are each homogenous in ethnicity, language, dressing, identity, and other cultural and social norms and values, the North-East, North Central, and South-South regions are an assemblage of different but related ethnic groups, language, and culture. Using a multistage sampling technique, a total of parous 64,206 women resident in the three homogeneous constituted the study population while 1939 of them who were migrants were purposively selected as the sample population. The comparison population consisted of 57,250 women who were both natives of and stayers at the home regions.

\section{Data source and variable description}

Data for the study were extracted from the report of the 2013 National Demographic and Health Survey (NDHS) in Nigeria. The NDHS, funded by the United States Agency for International Development (USAID) in Nigeria and the Department for International Development (DFID), is a nationally representative data collected from a cluster of enumeration areas in each of the 774 LGAs in the country using interviewer-administered questionnaires. The questionnaires, modeled to international DHS standards but modified to capture local specifics, were to elicit requisite information from households, women, and men. While the household questionnaire was used to collect basic information on usual members of a household such as age, sex, education, and marital status, and other general information on the household and housing characteristics, the men and women questionnaires focused on general issues affecting the sexes such as education, income, health, and fertility. The women questionnaire was more detailed on the subject of reproductive history, knowledge and usage of family planning methods, and fertility preferences. Both the men and women questionnaires were administered on respondents aged 15 to 49 .

From the women questionnaire, variables addressing age, region of residence, type of place of residence (whether urban or rural), highest educational attainment, religion, ethnicity, wealth index, and total number of children ever born were extracted for the study. These variables were captured as variables (V) 013, 024, 025, 106, 130, 131, 190, and 201 respectively in the DHS recode data file. As the study's interest is in women in and from the North-West, South-East, and South-West regions, variables 024 (region of residence) and 131 (ethnicity) were further recoded. The North-West was recoded as 1, South-East as 2, South-West as 3, and the other regions recoded as 'Others' and assigned a value of 4. For ethnicity, HausaFulani of the North-West region was coded as 1, Igbo of South-East coded as 2, and Yoruba of South-West coded as 3. The other 377 ethnic groups captured in the DHS were assigned code 4 as 'Others'. The NDHS data however did not cover some aspects of migration history. 
Length of stay in current location and reason for migration were not included in the datasets, hence the study could not distinguish among generations $1,1.5$, and 2 migrants in the study sample.

\section{Data analysis}

To compare the fertility behavior and sociodemographic confounders of migrants fertility behavior in their destination against what obtained in their places of origin and among the local population in the destination regions, the median number of children ever born (CEB) and the sociodemographic characteristics of the weighted general sample of women resident in the North-West, South-East, and South-West regions were first computed. Subsequently, univariate and bivariate analyses were conducted on the stayers and migrants' datasets at individual and ethnic group levels. This was to enable a comparison between both groups. Further, multivariate analysis was carried out the migrants' datasets to determine the predictors of their fertility behavior. Internal migrants in the study are respondents whose ethnicity differs from the ethnic group associated with their region of residence. Data on the number of children ever born and the sociodemographic characteristics of the respondents as well as their ethnic distributions were analyzed at the univariate level using frequency and percentage distribution. Measures of bivariate association employed included Chi-square test and correlations. The dependent variable for the study was the number of children ever born (CEB) by the migrants while their sociodemographic characteristics and ethnicity were the independent variables.

The CEB was employed in this study as a measure of fertility behavior because it describes the cumulative fertility of the women sample as at the time of the survey. As an indicator of fertility in developing countries, the CEB is easy to measure and serves as a useful corollary of measuring the effects of sociodemographic and other confounding variables on fertility (Farooq, 1985; Banougnin, 2019). Its shortcoming, notably underreporting of live births emanating from misreporting of age, omission, children not living with parents, or death of child, was adequately provided for in the DHS questionnaire used for the survey employed for this study. At the multivariate level, the Poisson pegression model was employed to determine the relationships between the number of children ever born and the sociodemographic variables. The choice of Poisson regression stems from the nature of the dependent variable as a count data that follows a discrete probability distribution with finite non-negative values. Poisson regression addresses the deficiencies associated with using linear regression to model dependent variables with non-negative values and is most suitable for non-linear count data using ordinal, nominal, or both types of datasets as predictors. Several studies have shown its application in modeling fertility (Little, 1978; Wang and Famoye, 1997; Poston, 2002; Dwivedi et al., 2016).

With a dependent variable $\mathrm{Y}(\mathrm{CEB})$ and six independent variables $\left(\mathrm{X}_{1} \ldots \mathrm{X}_{6}\right)$, the Poisson regression $(\mathrm{Pr})$ model is given as;

$$
\operatorname{Pr}\{Y=y\}=\frac{e^{-\mu} \mu^{y}}{y !} \text { for } \mu>0, y=0,1,2, \ldots
$$

where the $\log$ of the mean $\mu$ is assumed to be a linear function of the independent variables. That is; 


$$
\begin{aligned}
& \ln (\mu)=\alpha+\beta_{1} X_{1}+\beta_{2} X_{2}+\cdots+\beta_{6} X_{6}=x^{\prime} ; \\
& \text { where } x^{\prime}=\left[1 X_{1} X_{2} \cdots X_{6}\right]
\end{aligned}
$$

$\alpha$ is intercept and $\beta$ 's are the Poisson regression coefficients. This implies that $\mu$ is the exponential function of independent variables

$$
\mu=e^{\alpha+\beta_{1} X_{1}+\beta_{2} X_{2}+\ldots+\beta_{6} X_{6}}=e^{\alpha^{\prime} \beta}
$$

For migrant $i$;

$$
\operatorname{In}\left(\mu_{i}\right)=\alpha+\beta_{1} X_{1 i}+\beta_{2} X_{2 i}+\cdots+\beta_{6} X_{6 i}=x_{i}^{\prime} \beta
$$

Four regression models were generated. The first investigated the relationship between $\mathrm{CEB}$ and the predictors among all the migrants as a group while the three other models were on the relationships at ethnic group level. In other words, the second, third, and fourth models were on Hausa-Fulani, Igbo, and Yoruba migrants respectively. Statistical significance for all analyses was set at $P \leq 0.05$ and all the analyses were carried out using Microsoft Excel (2016 version) and the Statistical Package for Social Sciences (SPSS) version 20.

\section{Ethical considerations}

Ethical approval was granted to the DHS to conduct the survey and informed consent obtained from each respondent before the survey was carried out. Approval to use the NDHS datasets for this research was sought and obtained from the DHS Program via an authorization letter dated June 24, 2019.

\section{Results}

\section{Descriptive analysis and ethnic variations}

While the pattern of age distribution was similar between the general stayers and migrant samples, and between stayers and migrants in each ethnic group, the pattern differed slightly among the ethnic groups. Most Hausa-Fulani and Yoruba migrants were aged 35-39 while most Igbo migrants were aged 30-34. Further, Igbo and Yoruba had no migrant less than 20 years old unlike Hausa-Fulani migrants. Other sociodemographic characteristics also differed among the ethnic groups. For instance, while Catholics were $8 \%$ of the stayers in the general sample, Igbo Catholic stayers were $40.5 \%$. More than $99 \%$ of Hausa-Fulani stayers in the North-West practiced Islam while stayers who practiced Islam were $35.8 \%$ among the Yoruba of South-West regions. There were no Igbo or Hausa stayers that practiced Islam and Catholicism respectively. Only $4.4 \%$ of stayers had higher education compared with nearly $16 \%$ among migrants. About $68 \%$ of migrants were from rich households, whereas stayers in that wealth category were $31.2 \%$. While $61.6 \%$ of stayers resided in rural areas, two-thirds of the migrants lived in urban areas of their destination regions. More than $85 \%$ of Hausa-Fulani stayers had no formal education, $77.3 \%$ of Igbo stayers had either primary or secondary education, while the Yoruba ethnic group had the highest proportion of stayers with higher education (12.7\%). As illustrated in Table 1, Yoruba stayers also had the highest proportion of respondents in the rich wealth category $(80.2 \%)$. Nearly $24 \%$ of stayers had more than eight children while the proportion was $11.4 \%$ among the migrants. 
Table 1 Sociodemographic characteristics of stayers and migrants

\begin{tabular}{|c|c|c|c|c|c|c|c|c|}
\hline \multirow[t]{3}{*}{ Variable } & \multicolumn{2}{|c|}{ All Ethnic Groups } & \multicolumn{2}{|c|}{ Hausa-Fulani } & \multicolumn{2}{|l|}{ Igbo } & \multicolumn{2}{|l|}{ Yoruba } \\
\hline & Stayers & Migrants & Stayers & Migrants & Stayers & Migrants & Stayers & Migrants \\
\hline & $\%$ & $\%$ & $\%$ & $\%$ & $\%$ & $\%$ & $\%$ & $\%$ \\
\hline \multicolumn{9}{|l|}{ Age } \\
\hline $15-19$ & 1.3 & 0.5 & 1.7 & 1.2 & 0.5 & - & 0.4 & - \\
\hline $20-24$ & 6.0 & 4.1 & 7.3 & 3.9 & 4.0 & 4.3 & 3.6 & 4.3 \\
\hline $25-29$ & 14.7 & 11.9 & 16.5 & 11.3 & 11.4 & 12.9 & 12.1 & 8.5 \\
\hline $30-34$ & 17.6 & 21.8 & 17.9 & 19.2 & 16.1 & 24.0 & 18.1 & 21.3 \\
\hline $35-39$ & 20.1 & 24.9 & 19.9 & 27.2 & 18.7 & 22.6 & 22.3 & 26.6 \\
\hline $40-44$ & 18.4 & 20.4 & 16.2 & 24.9 & 22.8 & 17.8 & 21.3 & 14.9 \\
\hline $45-49$ & 22.0 & 16.5 & 20.6 & 12.3 & 26.5 & 18.3 & 22.2 & 24.5 \\
\hline \multicolumn{9}{|l|}{ Religion } \\
\hline Catholic & 8.0 & 23.2 & - & 9.4 & 40.5 & 37.6 & 1.4 & 5.3 \\
\hline Other Christian & 22.2 & 39.9 & 0.2 & 12.7 & 55.6 & 60.2 & 62.2 & 46.8 \\
\hline Islam & 68.6 & 37.0 & 99.3 & 77.9 & - & 2.2 & 35.8 & 47.9 \\
\hline Traditionalist & 0.8 & - & 0.1 & - & 3.5 & - & 0.5 & - \\
\hline Others & 0.4 & - & 0.5 & - & 0.4 & - & 0.1 & - \\
\hline \multicolumn{9}{|l|}{ Highest education } \\
\hline None & 57.3 & 31.8 & 85.2 & 72.5 & 14.1 & 4.0 & 7.4 & 7.4 \\
\hline Primary & 19.2 & 17.1 & 9.7 & 9.9 & 39.0 & 22.8 & 30.7 & 17.0 \\
\hline Secondary & 19.1 & 35.2 & 4.3 & 13.8 & 38.3 & 47.8 & 49.2 & 58.5 \\
\hline Higher & 4.4 & 15.9 & 0.7 & 3.9 & 8.6 & 25.4 & 12.7 & 17.0 \\
\hline \multicolumn{9}{|l|}{ Wealth Index } \\
\hline Poor & 51.7 & 25.9 & 73.7 & 60.5 & 24.9 & 3.4 & 4.9 & - \\
\hline Middle & 17.1 & 5.8 & 13.9 & 5.5 & 29.7 & 5.7 & 14.9 & 7.4 \\
\hline Rich & 31.2 & 68.3 & 12.4 & 34.0 & 45.4 & 90.9 & 80.2 & 92.6 \\
\hline \multicolumn{9}{|l|}{ Place of residence } \\
\hline Urban & 38.4 & 67.3 & 20.2 & 36.9 & 64.5 & 86.4 & 73.2 & 93.6 \\
\hline Rural & 61.6 & 32.7 & 79.8 & 63.1 & 35.5 & 13.6 & 26.8 & 6.4 \\
\hline \multicolumn{9}{|l|}{ Children ever born } \\
\hline $1-4$ & 29.9 & 47.1 & 23.2 & 28.9 & 31.3 & 59.3 & 51.2 & 59.6 \\
\hline $5-8$ & 46.6 & 41.4 & 44.9 & 46.2 & 53.1 & 37.9 & 45.5 & 40.4 \\
\hline $9+$ & 23.5 & 11.4 & 31.9 & 24.8 & 15.6 & 2.8 & 3.3 & - \\
\hline Number of observations & 57,250 & 1,939 & 35,762 & 778 & 10,970 & 973 & 10,518 & 188 \\
\hline
\end{tabular}

With 50.2\%, Igbo migrants constituted the majority of the migrant sample. Hausa-Fulani were $40.1 \%$ and Yoruba migrants were $9.7 \%$. The South-West, home of the Yoruba ethnic group, was however the destination of choice with $75 \%$ of the migrant population resident there. The North-West housed $15.7 \%$ of the migrants while $9.3 \%$ were in the South-East. Just as nearly $82 \%$ and $18.4 \%$ of the Hausa-Fulani migrants were resident in the SouthWest and South-East regions respectively, the proportions of Igbo migrants in the NorthWest and South-West were $15.8 \%$ and $84.2 \%$ respectively. There were more Yoruba migrants in the North-West (80.3\%) than in the South-East (19.7\%). The age distribution of the migrants indicates that there were few migrants aged 15-24 among the ethnic groups and Islam was the most prevalent religion among the respondents. As shown in 
Table 1, the Hausa-Fulani ethnic group had the highest proportion of migrants without formal education (72.5\%), from poor households on the wealth index (60.5\%), and dwelling in rural areas (63.1\%). No Yoruba migrant had more than eight children. With the exception of age in the general migrant sample, all the variations in the distribution were statistically significant at $P<0.001$.

\section{Ethnic fertility pattern and bivariate associations}

An analysis of the national sample on the number of children ever born among the three ethnic groups irrespective of place of residence, indicates that the Hausa-Fulani ethnic group ranked highest with a median CEB of 7. The Igbo and Yoruba recorded median CEB of 6 and 4 respectively. When the analysis was conducted at regional levels, excluding migrants, the averages were still 7, 6, and 4 for Hausa-Fulani, Igbo, and Yoruba in their North-West, South-East, and South-West home regions respectively. The CEB however varied for members of the ethnic groups away from their regions of origin. A comparison of the CEBs between the median CEB for each ethnic group at their place of origin and at destination, on the one hand, and between the ethnic group's median CEB at destination and the CEB of the home ethnic group at destination, on the other hand, shows that none of the ethnic groups retained their home region CEB across all their migration destination. As shown in Table 2, the HausaFulani migrants in the South-West retained their origin CEB of 7; three births more than the CEB of Yoruba ethnic group at the destination. In the South-East, they gave birth to an average of 5; one birth less than the hosts' CEB of 6 . The Igbo migrants in the North-West had a median CEB of 4.5; 1.5 short of the 6 at their home region and 2.5 less than their hosts' 7. In the South-West, the Igbo's median CEB was 4, same as their Yoruba hosts. On their own part, the Yoruba migrants retained their origin CEB of 4 in their North-West destination but had an increase in CEB to 5 in the South-East. In both instances, they recorded lesser births than their hosts.

An analysis of the association between CEB and the sociodemographic characteristics of the migrants and the comparison population of stayers shows that migrants had fewer number of children from age 25 relative to stayers in the same age group in the general sample. The pattern was also similar among Hausa-Fulani migrants from ages 25-39 and 45-49. The difference was from age 30 among Igbo migrants while Yoruba migrants recorded 0.5 births more than Yoruba stayers in the age group 25-29. The highest number of children in the general stayers and migrant sample was recorded among adherents of Islam. Igbo migrants who practiced Islam, as against the dominant Catholicism in their home region, also had more children than fellow migrants who were Catholics and other Christians. Progression in educational attainment was associated with lower births except among the Yoruba migrants. Hausa-Fulani migrants with

Table 2 Ethnic variations in CEB between stayers and migrants

\begin{tabular}{lllll}
\hline Ethnic group & Origin CEB & $\begin{array}{l}\text { North-West } \\
\text { destination CEB }\end{array}$ & $\begin{array}{l}\text { South-East } \\
\text { destination CEB }\end{array}$ & $\begin{array}{l}\text { South-West } \\
\text { destination CEB }\end{array}$ \\
\hline Hausa-Fulani & 7.0 & $\mathrm{HR}$ & 5.0 & 7.0 \\
lgbo & 6.0 & 4.5 & $\mathrm{HR}$ & 4.0 \\
Yoruba & 4.0 & 4.0 & 5.0 & $\mathrm{HR}$ \\
\hline
\end{tabular}

$H R$ home region 
at least secondary education as well as Igbo migrants with either primary or secondary education had fewer number of children compared with stayers of both ethnic groups in the same category. As further shown in Table 3, poorer population, stayers in rural areas and migrants who lived in the rural areas had more children. All the sociodemographic attributes were statistically significant $(P<0.001)$ in their association with the number of children ever born across all the samples except with place of residence and Igbo stayers' fertility $(P<0.05)$ and with respect to educational attainment, wealth status and place of residence among the Yoruba migrants.

\section{Multivariate analysis of migrants fertility behavior}

To investigate the influence of the sociodemographic factors on the fertility pattern of migrants, four Poisson regression models were employed. The first looked at all migrants irrespective of regions of residence or ethnic group while the three other models were ethnic group specific. The model fitting information was significant $(P<0.001)$ for all the models and the goodness of fit (value/df) was greater than 0.5 in all the four

Table 3 Sociodemographic dimensions of children ever born (stayers and migrants)

\begin{tabular}{|c|c|c|c|c|c|c|c|c|}
\hline \multirow{2}{*}{$\begin{array}{l}\text { Sociodemographic } \\
\text { variable }\end{array}$} & \multirow[t]{2}{*}{ All stayers } & \multirow[t]{2}{*}{ All migrants } & \multicolumn{2}{|c|}{ Hausa-Fulani } & \multicolumn{2}{|c|}{ Igbo stayers } & \multicolumn{2}{|c|}{ Yoruba stayers } \\
\hline & & & Stayer & Migrants & Stayer & Migrants & Stayer & Migrants \\
\hline \multicolumn{9}{|l|}{ Age } \\
\hline $15-19$ & 1.0 & 1.0 & 1.0 & 1.0 & 1.0 & - & 1.0 & - \\
\hline $20-24$ & 2.0 & 2.0 & 3.0 & 3.0 & 2.0 & 2.0 & 2.0 & 1.5 \\
\hline $25-29$ & 4.0 & 3.0 & 4.0 & 3.0 & 3.0 & 3.0 & 3.0 & 3.5 \\
\hline $30-34$ & 6.0 & 4.0 & 6.0 & 5.0 & 5.0 & 4.0 & 4.0 & 4.0 \\
\hline $35-39$ & 7.0 & 5.0 & 8.0 & 7.0 & 6.0 & 4.0 & 5.0 & 4.0 \\
\hline $40-44$ & 7.0 & 6.0 & 9.0 & 9.0 & 7.0 & 5.0 & 5.0 & 4.0 \\
\hline $45-49$ & 8.0 & 6.0 & 10.0 & 7.0 & 7.0 & 6.0 & 6.0 & 5.0 \\
\hline \multicolumn{9}{|l|}{ Religion } \\
\hline Catholic & 6.0 & 4.0 & 5.0 & 6.0 & 6.0 & 4.0 & 4.0 & 2.0 \\
\hline Other Christian & 5.0 & 4.0 & 5.0 & 7.0 & 6.0 & 4.0 & 4.0 & 4.0 \\
\hline Islam & 7.0 & 6.0 & 7.0 & 7.0 & 4.0 & 6.0 & 5.0 & 4.0 \\
\hline Traditionalist & 7.0 & - & 7.0 & - & 7.0 & - & 5.0 & - \\
\hline Others & 1.0 & - & 8.0 & - & 4.0 & - & 4.0 & - \\
\hline \multicolumn{9}{|l|}{ Highest education } \\
\hline None & 7.0 & 7.0 & 7.0 & 7.0 & 7.0 & 6.0 & 6.0 & 3.0 \\
\hline Primary & 6.0 & 6.0 & 6.0 & 7.0 & 7.0 & 5.0 & 5.0 & 4.5 \\
\hline Secondary & 4.0 & 4.0 & 5.0 & 4.0 & 5.0 & 4.0 & 4.0 & 4.0 \\
\hline Higher & 4.0 & 4.0 & 5.0 & 3.5 & 4.0 & 4.0 & 3.0 & 4.0 \\
\hline \multicolumn{9}{|l|}{ Wealth index } \\
\hline Poor & 7.0 & 7.0 & 7.0 & 7.0 & 7.0 & 6.0 & 6.0 & - \\
\hline Middle & 6.0 & 6.0 & 7.0 & 8.0 & 6.0 & 6.0 & 5.0 & 5.0 \\
\hline Rich & 5.0 & 4.0 & 6.0 & 4.0 & 5.0 & 4.0 & 4.0 & 4.0 \\
\hline \multicolumn{9}{|l|}{ Place of residence } \\
\hline Urban & 5.0 & 4.0 & 6.0 & 5.0 & 6.0 & 4.0 & 4.0 & 4.0 \\
\hline Rural & 7.0 & 7.0 & 7.0 & 7.0 & 6.0 & 6.0 & 5.0 & 5.0 \\
\hline
\end{tabular}


models. In the models, absolute number of children ever born was employed as the dependent variable while age, religion, highest educational attainment, wealth status, place of residence (whether urban or rural), and migration destination region were the predictors. The results, summarized in Table 4, show that the odds of having higher fertility behavior among all migrants increased with aspects of religion, and all levels of education and wealth status. This suggests that fertility decreased with increased education and wealth status. In a similar but reverse order, age of migrants was also significant in lowering the odds of having more children with the age group 15-24 having the lowest odds. Being resident in urban areas and destination region also lowered the likelihood of having more children but the odds were not statistically significant in the latter case.

Age recorded a similar influence among the Hausa-Fulani and Igbo migrants but only in the age groups 20-24 and 30-34 did it significantly affect the number of children ever born among Yoruba migrants. Unlike with age, the three ethnic groups did not have the same pattern of outcomes on any of the other predictors. For instance, while religion was statistically significant among the Hausa-Fulani, it was not with Igbo and Yoruba migrants. All levels of education increased the likelihood of having more children among the Hausa-Fulani and Igbo, and significantly so. Education however lowered the odds among the Yoruba migrants. Relative to the rich wealth index, all other level of wealth significantly increased the likelihood of having higher fertility behavior among Hausa-Fulani migrants. The odds varied among the poor and middle classes among the Yoruba and Igbo and were not statistically significant. Urban residence lowered the odds among all the ethnic groups but was only significant among the Igbo.

\section{Discussion}

The highest numbers of children in the general sample were associated with the HausaFulani and Igbo ethnic groups. In these ethnic groups, Islam and Catholicism were the most prevalent religion respectively. The findings are consistent with the general notion on the disposition of both religion to family planning and contraceptive use in particular (Jones and Nortman, 1968; Omran, 1990; Hasna, 2003; LeMaire, 2016). The median CEB of 4 among the Yoruba as against the 7 and 6 for Hausa-Fulani and Igbo may be due to the religious composition of the South-West region. About $62 \%$ of the population were Christians of other denominations. These include the Protestants and the more liberal Pentecostal movements. In addition to them, Islamic faithful (33.1\%), Catholics (4.2\%), and Traditionalists $(0.5 \%)$ made up the population of the region. Stonawski et al. (2016) and Adedini et al. (2018) have shown evidence of the influence of religion on fertility patterns and contraceptive use in Nigeria. Of more significant influence, however, are the contributions of education and wealth. While only $1.2 \%$ of women in the Hausa-Fulani North-West region had higher education, the figure was $8.7 \%$ in the Igbo South-East and $11.6 \%$ in the South-West region. Nearly three out of four Yoruba women were above the middle-income wealth status as against $46 \%$ and $14 \%$ among the Igbo and Hausa-Fulani. These findings align with previous studies that have found an association between fertility and higher education, and wealth in Nigeria (Adeyemi et al., 2016; Ofonime, 2017).

The fertility behavior of migrants in Nigeria, as shown in this study, presents interesting findings. The Igbo migrants, with an origin CEB of 6, recorded lower births in their two destination regions. While they had an average of 4.5 in the North-West whose Hausa-Fulani population had an average of 7 , they recorded an average of 4 in the 
Table 4 Poisson regression model summary

\begin{tabular}{|c|c|c|c|c|c|c|c|c|}
\hline \multirow{2}{*}{$\begin{array}{l}\text { Model } \\
\text { Covariates }\end{array}$} & \multicolumn{2}{|c|}{$\begin{array}{l}\text { Model } 1 \\
\text { All migrants }\end{array}$} & \multicolumn{2}{|c|}{$\begin{array}{l}\text { Model } 2 \\
\text { Hausa-Fulani migrants }\end{array}$} & \multicolumn{2}{|c|}{$\begin{array}{l}\text { Model } 3 \\
\text { Igbo migrants }\end{array}$} & \multicolumn{2}{|c|}{$\begin{array}{l}\text { Model } 4 \\
\text { Yoruba migrants }\end{array}$} \\
\hline & $\begin{array}{l}\text { Odds } \\
\text { ratio }\end{array}$ & $\begin{array}{l}\text { Standard } \\
\text { error }\end{array}$ & $\begin{array}{l}\text { Odds } \\
\text { ratio }\end{array}$ & $\begin{array}{l}\text { Standard } \\
\text { error }\end{array}$ & $\begin{array}{l}\text { Odds } \\
\text { ratio }\end{array}$ & $\begin{array}{l}\text { Standard } \\
\text { error }\end{array}$ & $\begin{array}{l}\text { Odds } \\
\text { ratio }\end{array}$ & $\begin{array}{l}\text { Standard } \\
\text { error }\end{array}$ \\
\hline \multicolumn{9}{|l|}{ Age } \\
\hline $15-19$ & $0.129^{* *}$ & 0.335 & $0.139^{* *}$ & 0.336 & - & - & - & - \\
\hline $20-24$ & $0.335^{* *}$ & 0.079 & $0.334^{* *}$ & 0.121 & $0.338^{* *}$ & 0.113 & $0.276^{* *}$ & 0.304 \\
\hline $25-29$ & $0.519^{* *}$ & 0.044 & $0.490^{* *}$ & 0.070 & $0.524^{* *}$ & 0.063 & 0.752 & 0.180 \\
\hline $30-34$ & $0.734^{* *}$ & 0.033 & $0.825^{* *}$ & 0.053 & $0.663^{* *}$ & 0.049 & $0.688^{*}$ & 0.142 \\
\hline $35-39$ & $0.831^{* *}$ & 0.031 & $0.909^{*}$ & 0.048 & $0.753^{* *}$ & 0.046 & 1.027 & 0.128 \\
\hline $40-44$ & 0.944 & 0.031 & 1.066 & 0.047 & $0.794^{* *}$ & 0.049 & 0.937 & 0.125 \\
\hline $45-49$ & $\mathrm{RC}$ & & $\mathrm{RC}$ & & $\mathrm{RC}$ & & $\mathrm{RC}$ & \\
\hline \multicolumn{9}{|l|}{ Religion } \\
\hline Catholic & $1.164^{*}$ & 0.055 & $1.388^{* *}$ & 0.095 & 1.061 & 0.164 & 0.720 & 0.242 \\
\hline Other Christian & 1.074 & 0.049 & $1.277^{* *}$ & 0.074 & 0.969 & 0.161 & 0.993 & 0.092 \\
\hline Islam & $\mathrm{RC}$ & & $\mathrm{RC}$ & & $\mathrm{RC}$ & & $\mathrm{RC}$ & \\
\hline \multicolumn{9}{|l|}{ Highest education } \\
\hline None & $1.287^{* *}$ & 0.061 & $1.480^{* *}$ & 0.119 & $1.376^{* *}$ & 0.098 & 0.739 & 0.221 \\
\hline Primary & $1.257^{* *}$ & 0.043 & $1.343^{*}$ & 0.124 & $1.285^{* *}$ & 0.051 & 0.987 & 0.141 \\
\hline Secondary & $1.201^{* *}$ & 0.036 & 1.126 & 0.109 & $1.243^{* *}$ & 0.042 & 0.886 & 0.132 \\
\hline Higher & $\mathrm{RC}$ & & $\mathrm{RC}$ & & $\mathrm{RC}$ & & $\mathrm{RC}$ & \\
\hline \multicolumn{9}{|l|}{ Wealth index } \\
\hline Poor & $1.207^{* *}$ & 0.046 & $1.226^{* *}$ & 0.062 & 1.012 & 0.118 & - & - \\
\hline Middle & $1.166^{* *}$ & 0.049 & $1.363^{* *}$ & 0.075 & 0.991 & 0.073 & 1.416 & 0.181 \\
\hline Rich & $\mathrm{RC}$ & & $\mathrm{RC}$ & & $\mathrm{RC}$ & & $\mathrm{RC}$ & \\
\hline \multicolumn{9}{|l|}{ Place of residence } \\
\hline Urban & $0.907^{*}$ & 0.037 & 0.923 & 0.060 & $0.832^{* *}$ & 0.054 & 0.946 & 0.209 \\
\hline Rural & $\mathrm{RC}$ & & $\mathrm{RC}$ & & $\mathrm{RC}$ & & $\mathrm{RC}$ & \\
\hline \multicolumn{9}{|l|}{ Region } \\
\hline North-West & 0.959 & 0.040 & - & - & 1.033 & 0.046 & 0.828 & 0.111 \\
\hline South-East & 0.975 & 0.056 & 0.894 & 0.082 & - & - & $\mathrm{RC}$ & \\
\hline South-West & $\mathrm{RC}$ & & $\mathrm{RC}$ & & $\mathrm{RC}$ & & - & - \\
\hline
\end{tabular}

South-West to match with their Yoruba hosts. Almost 78\% of the Igbo migrants in the North-West belonged to rich households on the wealth index compared with $12.4 \%$ in the host population. About $19 \%$ of them also had higher education relative to $0.7 \%$ in the host population and $82 \%$ lived in urban areas of the North-West. More than $93 \%$ of the Igbo migrants in South-West Nigeria were rich, $26.6 \%$ had higher education and 87.3\% lived in urban areas. When these figures are compared along origin and destination lines, the Igbo migrants fared much better than the Igbo stayers in terms of socioeconomic characteristics and this may explain why they have lower CEB compared to the origin CEB. More Igbo stayers than migrants were also aged 45 and above and would have more cumulative births than those in younger age groups. As shown in the bivariate and multivariate analysis, wealth status, education and place of residence mattered for fertility behavior among the migrants. 
The Hausa-Fulani migrants maintained their origin CEB of 7 in South-West Nigeria. They however recorded an average of 5 CEB in the South-East. About $71 \%$ of the HausaFulani migrants in the South-West were poor, $87.7 \%$ of them had no formal education and nearly $74 \%$ of them lived in rural areas of the South-West. When compared with the sociodemographic situation in their North-West origin, both samples shared similar characteristics. At home, $73.7 \%$ were poor, $85.2 \%$ had no education, and $79.8 \%$ lived in rural area. These similarities are therefore reflected in the CEB of 7 at home and in the SouthWest destination. In the South-East however, $76.3 \%$ of the Hausa-Fulani migrants were rich, $81.8 \%$ of them had either primary or secondary education, and $84.6 \%$ lived in urban areas. By all standards, therefore, and like the Igbo migrants in the North-West and South-West regions, the Hausa-Fulani migrants in the South-East were very much better than the stayers in their home region. These upper-class socioeconomic characteristics must have influenced their CEB of 5 which is not only lower than origin CEB but also lower than hosts' CEB in their South-East destination.

The Yoruba migrants in the North-West shared similar attributes with the origin population and also maintained their origin CEB of 4 in the North-West region. More than $92 \%$ of them were rich, only $7.4 \%$ had no formal education, and over $93 \%$ lived in urban areas. In the South-East however, in spite having $86.5 \%$ of the sample in the rich wealth category, and having no single member without education or attending the Catholic church, they had a CEB of 5. Although a birth less than the hosts' 6, their South-East CEB was one birth more than the CEB of the Yoruba stayers. A further interrogation of the results shows that while the migrants' ages were almost evenly spread across all age groups in the North-West, similar to what obtained in the origin South-West, Yoruba migrants in the South-East were aged mainly between 30 and 39 . More than $78 \%$ of the sample were in this category. This age range has been found to have a higher fertility rate and interval owing to the delay of education as well as personal and career aspirations (Mathews and Hamilton, 2009; Balasch and Gratacos, 2012; Bellieni, 2016). About 16\% of the migrants were also adherents of Islam in a region with the lowest number of Islamic faithful.

From the fertility behavior exhibited by the ethnic migrants in their destinations relative to their home region, the adaptation hypothesis is valid in explaining the reduction in the Igbo migrants' CEB in the South-West. Evidence of adaptation has also been found in migrants fertility behavior in Estonia, Turkey and Benin Republic (Kulu, 2005; Eryurt and Koc, 2012; Banougnin et al., 2018). The Hausa-Fulani migrants in the South-West had an average CEB that mirrored what obtained in their home region. This suggests that the Hausa-Fulani exhibited the basic feature of the socialization hypothesis. In like manner, having an average of 4 births that characterized the Yoruba in the South-West and in their destination North-West typifies the socialization hypothesis. Goldstein and Goldstein (1984), Milewski (2010), Krapf and Wolf (2015) and Anglewicz et al. (2017) found similar results in their study of migrant fertility behavior in Malaysia, Germany, and Congo. With a birth more than the origin CEB of 4, and tending toward converging with the CEB of 6 in the South-East, the ethnic Yoruba migrants in the South-East can also be said to be adapting. Both hypotheses however fail to describe the fertility behavior of Igbo migrants in the North-West and Hausa-Fulani migrants in the South-East which showed that migrants from both ethnic groups had fewer births than what obtained in their origin and destinations. 
Exhibiting a fertility behavior that is different from what obtains at both origin and destination, as found out among the Igbo migrants in the North-West and the HausaFulani in the South-East, are consistent with the selectivity hypothesis and findings in studies by Hervitz (1985) and González-Ferrer et al. (2017). The selectivity hypothesis suffices in describing the fertility patterns of the Igbo migrants in the North-West and Hausa-Fulani migrants in the South-East as evidence shows that the socioeconomic characteristics of both sets of migrants differed from those of the stayers' population in their home regions and those of the destination population. Reason for migration and other social and economic aspirations of the migrants may be responsible for the difference as have been shown by Omondi and Ayiemba (2005) in Kenya. Although at bivariate levels and the multivariate level of all migrants, there exist significant associations and relationships between fertility behavior and the sociodemographic covariates investigated in this study, the relationships assumed an ethnic dimension at the level of individual ethnic group. While age, education, and wealth increased the odds of having higher fertility behavior among the Igbo migrants, religion and place of residence in addition to education and wealth increased the likelihood among Hausa-Fulani migrants. Increase in wealth status and having higher education reflected copiously in the fertility behavior of Igbo migrants in the South-West and North-West as well as in the number of children born by the Hausa-Fulani migrants in the South-East.

\section{Conclusion}

Not only does fertility behavior vary among ethnic groups and their geographical habitations, ethnic migrants also carry this aspect of their cultural and social values to their migration destinations. In other instances, they adapt to the destination fertility behavior or simply carve a fertility profile that mirrors neither that of the origin or destination population. As found in this study, the adaptation, socialization, and selectivity hypotheses of migrant fertility hold true among the Hausa-Fulani, Igbo and Yoruba migrants. The fertility patterns observed were also influenced by the migrants' age, religion, educational attainment, wealth status, and type of place of residence. We suggest that to achieve the targets of the national population policy with its consequences for population and national development, concerted efforts should be made to improve the socioeconomic profile of households. The population's access to higher education should also be enhanced as this was found to have a significant consequence for migrants' fertility behavior in the study area. Whether the Hausa-Fulani socialization in the South-West carries with it a political dimension, or not, requires a deeper probe however.

\section{Limitation}

Though conducted since 2018, the reports and datasets of the most recent National Demographic and Health Survey (NDHS) in Nigeria are yet to be released as at the time of this study. This study was therefore conducted using the 2013 NDHS. In the survey, data on length of migration and purpose of migration were not captured. For this reason, a categorization of migrants according to their generation was not possible. While the categorization would have illuminated the pattern of fertility behavior among generations 1, 1.5, and 2 migrants and allow for a comparison, its absence does not affect the study outcomes. 


\section{Abbreviations}

CEB: Children ever born; DFID: Department for International Development; EA: Enumeration area; LGA: Local government area; NDHS: Nigeria Demographic and Health Survey; NPC: National Population Commission of Nigeria; USAID: United States Agency for International Development

\section{Acknowledgments}

We appreciate the DHS program and the National Population Commission of Nigeria for granting access to the Nigeria DHS data.

\section{Authors' contributions}

COO contributed the conception and design. YA acquired, analyzed, and interpreted the data and drafted the manuscript. Both authors contributed to the revision of intellectual content, read and approved the final manuscript.

\section{Funding}

No specific funding has been provided for this study.

\section{Availability of data and materials}

The dataset supporting the conclusions of this article is available in the online DHS archive [https://dhsprogram. com/ data/available-datasets.cfm]. Permission from the DHS program is required to access the data.

\section{Competing interests}

The authors declare that they have no competing interest.

Received: 9 September 2019 Accepted: 18 February 2020

Published online: 04 March 2020

\section{References}

Abizu, S. O. (2018). Migration as a livelihood diversification strategy of poor rural household in Edo State, Nigeria. International Journal of Humanities and Social Science, 8(8), 79-85.

Adebowale, A.S. (2019). Ethnic disparities in fertility and its determinants in Nigeria. Fertility Research and Practice. (2019) 5:3

Adedini, S. A., Babalola, S., Ibeawuchi, C., Omotoso, O., Akiode, A., \& Odeku, M. (2018). Role of religious leaders in promoting contraceptive use in nigeria: evidence from the Nigerian Urban Reproductive Health Initiative. Global Health Science Practice, 6(3), 500-514.

Adepoju, A. (1978). Migration and rural development in Nigeria, In Binsbergen, W.M.J and Meilink, H.A (eds). Migration and the Transformation of Modern African Society, Africa- Studiecentrum, Leiden

Adepoju, A. (1982). Pattern of migration, living conditions and community development in rural areas of South-West Nigeria. Federal Ministry of Social Development. Sports and Culture (Social Development Directorate), Lagos: Youth.

Adeyemi, A. S., Olugbenga-Bello, A. I., Adeoye, O. A., Salawu, M. O., Aderinoye, A. A., \& Agbaje, M. A. (2016). Contraceptive prevalence and determinants among women of reproductive age group in Ogbomoso, Oyo State. Nigeria. Open Access Journal of Contraception, 2016(7), 33-41.

Ajaero, C. K., \& Madu, I. A. (2014). Rural-urban migration and livelihoods in South Eastern Nigeria. Developing Country Studies, $4(6), 6-15$.

Akinyemi, J. O., Odimegwu, C., \& Adebowale, A. S. (2017). The effect of internal migration, individual and contextual characteristics on contraceptive use among Nigeria women. Health Care for Women International, 38(10), 1075-1094.

Alaba, O.O., Olubusoye, O.E. and Olaomi, J.O (2017) Spatial patterns and determinants of fertility levels among women of childbearing age in Nigeria, South African Family Practice, 59(4):143-147

Anglewicz, P., Corker, J., \& Kayembe, P. (2017). The fertility of internal migrants to Kinshasa. Genus, 73, 4.

Aworemi, J. R., \& Abdul-Azeez, I. A. (2011). An appraisal of the factors influencing rural-urban migration in some selected local government areas of Lagos State Nigeria. Journal of Sustainable Development, 4(3), 136-141.

Balasch, J. and Gratacós, E. (2012). Delayed childbearing: effects on fertility and the outcome of pregnancy. Current Opinion in Obstetrics and Gynecology, 2012;24:187-193

Banougnin, B.H. (2019). Patterns of migrants' fertility in Cotonou, Benin Republic. Unpublished PhD Thesis, Pan African University, Life and Earth Science Institute, University of Ibadan, Nigeria.

Banougnin, B.H., Adekunle, A.O., Oladokun, A. and Sanni, M.A. (2018). Impact of internal migration on fertility in Cotonou, Benin Republic. African Population Studies, 32(2): 4305-4318. 2018

Barber, J. S. (2000). Intergenerational influences on the entry into parenthood: mothers' preferences for family and nonfamily behavior. Social Forces, 79, 319-348.

Bellieni, C. (2016). The Best Age for pregnancy and undue pressures. journal of family and reproductive health, 10(3): 104107.

Dwivedi, V. K., Sediadie, T., \& Ama, N. O. (2016). Factors affecting children ever born (CEB) in Botswana: application of Poisson regression model. Research Journal of Mathematical and Statistical Sciences, 4(10), 1-9.

Eryurt, M.A. and Koc, I. (2012). Internal migration and fertility in Turkey: Kaplan-Meier survival analysis. International Journal of Population Research, Volume 2012

Farooq, G. M. (1985). The Definition of Fertility: Measurement issues. In G. M. Farooq \& G. B. Simmons (Eds.), Fertility in Developing Countries. London: Palmgrave Macmillan.

Farrell, K. (2018). An inquiry into the nature and causes of Nigeria's rapid urban transition. Urban Forum, 29(3), 277-298.

Fiori, F., Graham, E., \& Feng, Z. (2014). Geographical variations in fertility and transition to second and third birth in Britain Advances in Life Course Research, 21(2014), 149-167.

Frank, R., \& Heuveline, P. (2005). A crossover in Mexican and Mexican-American fertility rates: evidence of explanations for an emerging paradox. Demographic Research, 12(4), 77-104. 
Goldstein, S., \& Goldstein, A. (1983). Migration and fertility in peninsula Malaysia: an Analysis using life history data. In Rand Corporation Report \# N- 1860- AID. Santa: Monica.

Goldstein, S., \& Goldstein, A. (1984). Inter-relations between migration and fertility: their significance for urbanisation in Malaysia. Habitat International, 8(1), 93-104.

González-Ferrer, A., Castro-Martín, T., Kraus, E. K., \& Eremenko, T. (2017). Childbearing patterns among immigrant women and their daughters in spain: over-adaptation or structural constraints? Demographic Research, 37(19), 599-634.

Gugler, J. (1991). Life in a dual system revisited: urban-rural ties in Enugu, Nigeria, 1961-1987. World Development, 19(5), 399-409.

Gyimah, S. O. (2006). Migration and fertility behavior in Sub-Saharan Africa: the case of Ghana. Journal of Comparative Family Studies, 37(2), 235-252.

Hasna, F. (2003). Islam, social traditions and family planning. Social Policy and Administration, 37(2), 181-197.

Hervitz, H. M. (1985). Selectivity, adaptation, or disruption? A comparison of alternative hypotheses on the effects of migration on fertility: the case of Brazil. The International Migration Review, 19(2), 293-317.

Jones, G., \& Nortman, D. (1968). Roman Catholic fertility and family planning: a comparative review of the research literature. Studies in Family Planning, 1(34), 1-27.

Jung, M., Ko, W., Choi, Y., \& Cho, Y. (2019). Spatial variations in fertility of South Korea: A Geographically Weighted Regression Approach. ISPRS International Journal of Geo-Information, 8(6), 262.

Krapf, S., \& Wolf, K. (2015). Persisting differences or adaptation to German fertility patterns? First and Second Birth Behavior of the 1.5 and Second Generation Turkish Migrants in Germany. Köln Z Soziol, 67, 137-164.

Kulu, H. (2005). Migration and fertility: competing hypotheses re-examined. European Journal of Population (2005) 21: 51-87

Kulu, H. (2013). Why do fertlity levels vary between urban and rural areas? Regional Studies, 47(6), 895-912.

Kulu, H., \& Boyle, P. J. (2009). High fertility in city suburbs: compositional or contextual effects? European Journal of Population, 25(2), 157-174.

Kulu, H., Milewski, N., Hannemann, T., \& Mikolai, J. (2019). A decade of life-course research on fertility of immigrants and their descendants in Europe. Demographic Research, 40(46), 1345-1374.

Lee, B. S., \& Pol, L. G. (1993). The influence of rural-urban migration on migrants' fertility in Korea, Mexico and Cameroon. Population Research and Policy Review, 12, 3.

LeMaire, W. J. (2016). The Roman Catholic Church and Contraception. International Journal of Reproduction, Contraception, Obstetrics and Gynecology, 5(6), 2065-2068.

Liang, Y., Yi, Y., \& Sun, Q. (2014). The impact of migration on fertility under China's underlying restrictions: a comparative study between permanent and temporary migrants. Social Indicators Research, 116(1), 307-326.

Little R.J.A. (1978). Generalized linear models for cross-classified data from the WFS. World Fertility Survey Technical Bulletins, No. 5. 25.

Makinwa-Adebusoye, P.K. (1985): Migrant/non-migrant fertility differentials in urban Nigeria. Journal of the Population Association of Nigeria, Vol. 1, No. 1

Matthews, T. J., \& Hamilton, B. E. (2009). Delayed childbearing: more women are having their First Child Later in Life. NCHS Data Brief, 2009(21), 1-8.

Mberu, B., \& Reed, H. E. (2014). Understanding subgroup fertility differentials in Nigeria. Population Review, 53(2), 23-46.

Mberu, B. U. (2005). Who moves and who stays? Rural out-migration in Nigeria. Journal of Population Research, 22(2), 141-161.

Mberu, B. U., \& White, M. J. (2011). Internal migration and sexual initiation among never married youths in Nigeria. Social Science and Medicine, 72(8), 1284-1293.

Milewski, N. (2007). First child of immigrant workers and their descendants in West Germany: interrelation of events, disruption or adaptation? Demographic Research, 17(29), 859-895.

Milewski, N. (2010). Fertility of immigrants—a two-generational approach in Germany. Berlin: Springer

Milewski, N. (2011). Transition to a first birth among Turkish second-generation migrants in Western Europe. Advances in Life Course Research, 16, 178-189.

National Population Commission (NPC) [Nigeria] and ICF. (2019). Nigeria Demographic and Health Survey 2018 Key Indicators Report. In Abuja, Nigeria, and Rockville. Maryland, USA: NPC and ICF.

National Population Commission (NPC) [Nigeria] and ICF International. (2014). Nigeria Demographic and Health Survey 2013. Abuja, Nigeria, and Rockville, Maryland, USA: NPC and ICF International

National Population Commission (NPC) Nigeria. (1988). Nigeria Population Policy. Abuja: Government Press.

National Population Commission (NPC) Nigeria. (2004). National Policy on Population for Sustainable Development. Abuja: National Population Commission.

Nauck, B. (2001). Social capital, intergenerational transmission and intercultural contact in immigrant families. Journal of Comparative Family Research, 32, 465-489.

Odimegwu, C., \& Adedini, S. (2017). The role of community structure in shaping African Fertility Patterns: Evidence from Demographic and Health Surveys. Journal of Biosocial Science, 49(1), 46-61.

Odimegwu, C. O. (1999). Family planning attitudes and use in Nigeria: a factor analysis. International Family Planning Perspectives, 25(2), 86-91.

Odimegwu, C. O., Adedini, S. A., Ononokpono, D. N., \& Imasiku, E. N. S. (2014). Couple characteristics and fertility decisionmaking in Imo State, Nigeria: evidence from historical data. Southern African Journal of Demography, 15(1), 101-132.

Ofonime, E. J. (2017). Determinants of modern contraceptive uptake among Nigerian Women: evidence from the national demographic and health survey. African Journal of Reproductive Health, 21(3), 89-95.

Omondi, C. O., \& Ayiemba, E. H. O. (2005). Fertility differentials in Kenya: the effect of female migration. African Population Studies, 20(2), 25-41.

Omoyeni, T. S. (2013). Migration and family formation dynamics in nigeria: an exploration of linkages between migration and reproductive behaviour. Busan: IUSSP.

Omran, A. R. (1990). Children rights in Islam from the Qur'an and Sunnah. Population Science, 9, 77-88.

Oyeniyi, A. (2013). Internal migration in Nigeria: a positive contribution to human development. In ACP observatory on migration: Research Report ACPOBS/2013/PUB01. Affiliation: International Organization for Migration.

Poston, D. L. (2002). The statistical modelling of the fertility of chinese women. Journal of Modern and Applied Statistical Method, 1, 387-396. 
Rojas, G., Bernardi, L., \& Schmid, F. (2018). First and second births among immigrants and their descendants in Switzerland. Demographic Research, Volume 38. Article, 11, 247-286.

Saikia, N., Modahvaj, Saha, A., \& Chutia, U. (2019). Actual and ideal fertility differential among natives, immigrants, descendants of immigrants in a Northeastern State of India. Population, Space and Place, 2019, 25.

Smith, D. J. (2004). Youth, sin and sex in Nigeria: christianity and HIV/AIDS-related beliefs and behaviour among rural-urban migrants. Culture, Health \& Sexuality, 6, 425-437.

Stonawski, M., Potancokova, M., Cantele, M., \& Vegard, S. J. (2016). The changing religious composition of Nigeria: causes and implications of demographic divergence. Journal of of Modern African Studies, 54(3), 1-27.

United Nations (2019). World Population Prospects: 2019 Highlights. United Nations, Department of Economic and Social Affairs, Population Division, Geneva

Ushie, M. A., Ogaboh, A. A. M., Olumodeji, E. O., \& Attah, F. (2011). Socio-cultural and economic determinants of fertility differentials in rural and urban cross Rivers State, Nigeria. Journal of Geography and Regional Planning, 4(7), 383-391.

Wang, W., \& Famoye, F. (1997). Modeling household fertility decisions with generalized Poisson regression. Journal of Population Economics, 10(3), 273-283.

\section{Publisher's Note}

Springer Nature remains neutral with regard to jurisdictional claims in published maps and institutional affiliations.

Submit your manuscript to a SpringerOpen ${ }^{\circ}$ journal and benefit from:

- Convenient online submission

- Rigorous peer review

Open access: articles freely available online

High visibility within the field

- Retaining the copyright to your article

Submit your next manuscript at $\boldsymbol{\nabla}$ springeropen.com 